Is There a Relationship between Ritual and Cliché?:

Indigenous Fijian Criticism of Kava Drinking

Matt Tomlinson

Department of Social Anthropology

University of Oslo

Oslo, Norway

College of Asia and the Pacific

Australian National University

Canberra, Australia

matthew.tomlinson@sai.uio.no

ORCID ID 0000-0001-9808-7615 


\title{
Is There a Relationship between Ritual and Cliché?: Indigenous Fijian Criticism of Kava Drinking
}

\begin{abstract}
This article poses the question of what analytical insight can be gained by comparing ritual and cliché, both of which involve evaluations of the significance of repetition. The case study is kava-drinking sessions in indigenous Fiji. Whether purposeful or casual, kava-drinking sessions always follow rules which give them significant form and regularity of the kind some anthropologists consider definitive of ritual practice. Yet many indigenous Fijians criticise present-day kava-drinking sessions for several reasons. One prominent line of criticism is that kava drinking is now a matter of too much repetition- too many people drinking too much too often - and losing the meaningful link to chiefly tradition as a result. Analysing criticism of ritual in terms of cliché clarifies situations in which the iconic force of repetition is treated as an index of excess.
\end{abstract}

Keywords: ritual, cliché, kava, repetition, Fiji

Word count: 8914

Funding details: The most recent research for this article was supported by an Australian Research Council Future Fellowship (\#FT110100524, "Divine Power in Indigenous Christianity: Translation, Theology, and Pacific Politics”).

Disclosure: No financial interest or benefit has arisen from direct applications of this research. 
Is there a relationship between ritual and cliché? I begin with this question despite realising that it has three inherent problems. First, there is no firmly established anthropological consensus on a definition of ritual. Second, anthropologists have not taken up cliché as an analytic term. Third, cliché is usually characterised as something every thoughtful author should avoid. Nonetheless, I want to start here, because the question calls attention to the ways repetition becomes a focus of evaluation. Ritual and cliché both require an identification of what counts as 'sameness' and evaluation of that sameness. Another way to put the title question, then, might be: why is some repetition considered effective and meaningful, and some repetition considered empty and meaningless?

In this article, I examine ritualised drinking of the beverage kava (yaqona) in indigenous Fiji and Fijian criticism of it. I begin with a brief discussion of repetition and replication in anthropology and a consideration of the topic of cliché. Next I describe kavadrinking sessions, noting their regular patterns. I discuss indigenous Fijian criticisms of present-day kava drinking, which fall into two main kinds. One criticism is that kava can be used to summon dangerous spiritual presences and should be rejected in the Christian present. Another criticism frames kava-drinking as a kind of cliché. Although I have not heard people in Fiji explicitly use the term "cliché," the logic of the accusation is the same: A meaningful form has lost significance through excessive repetition. By focusing on critics' emphases on iconic and indexical properties of kava-drinking sessions, I argue, one can see how ritual is vulnerable to the same denunciation as cliché: that a form has been repeated too often by too 
many, with repetition pointing to the loss of meaning rather than the recreation or intensification of it.

The purposes of this article are to give insights into indigenous Fijian commentary on kava-drinking ritual, and, inspired by the ethnography, to ask whether cliché - that term and topic despised in academic discourse for marking unoriginality and tiredness — can be part of anthropology's critical conceptual repertoire.

\section{Repetition and the Problem of Cliché}

Many anthropologists of ritual have highlighted repetition, identifying it as a key feature of ritual processes and effects (e.g., Kertzer 1988; Myerhoff 1984; Rappaport 1999). For Maurice Bloch, the repetition of invariant forms of expression in ritual legitimises existing relations of domination (Bloch 1974, 1986). The true 'meaning' of repetition in ritual is the sanctification of convention with an aura of timelessness. Stanley Tambiah, critiquing Bloch, developed a performative model of ritual in which repetition can open up creative possibilities (Tambiah 1985). In ritual, multimodal expressions iconically represent cosmic order and indexically 'point to' social order. For Tambiah, ritual expression works partly through the patterned repetition of 'condensed' form in a process which can 'produce intensification of meaning as well as the decline of meaning' (1985: 137). Although Bloch's and Tambiah's approaches have been critiqued from many quarters (see Kelly and Kaplan 1990 and Stasch 2011 for discussions), they remain usefully counterposed models for considering relationships between formal repetition and the perceived enhancement or diminution of meaning.

A valuable contribution to studies of repetition in ritual comes from linguistic anthropologists who have focused on 'replication' as a distinct kind of repetition, one which calls attention to ways in which repetition both limits and enables creative expression. 
Replication is the uptake of circulating signs and texts and use of them in new contexts. Greg Urban characterises replication in terms of an iconic relationship, defining it as 'the creation of a new thing that shares the abstract form of an older one' (2001: 42). Patrick Eisenlohr (2010) defines replication by focusing on performers' denial of authorship. With reference to scriptural recitation by Mauritian Muslims, he writes that in replication one aims 'to reproduce a more or less precise token of the text... while making it clear that the performers uttering it are by no means...the originators responsible for the text' (2010: 321 ; see also Shoaps 1999, 2002). Even when authorship is denied, replication is minimally creative to the extent that texts are brought into new contexts.

Replication is an evaluation as well as a process. Obviously, people can have markedly different understandings of what 'counts' as replication; what counts as a new instance of an old form requires recognition of some similarities and erasure of many differences. The act of recognising replication is further entangled with judgments of what counts as proper or desirable replication. Everything I have said so far is perhaps obviousor, worse, anthropologically clichéd in its approach to ritual via textuality—but I want to lay it out explicitly because in the sections that follow I argue that for some ritual actors, replication becomes a problem when it is seen as too successful.

The topic of cliché usefully calls attention to how one ideology of replication works. The term 'cliché' is applied to expressions thought to be 'overused' and as a result to have 'lost originality, ingenuity, and impact' (Hargraves 2014: 3-4). In English, the labelling of something as a cliché is a historical product of the late nineteenth century (Lerner 1956: 261; see also Amossy 1982). The composers and performers of oral epics, working with wellknown formulas (the wine-dark sea, the rose-fingered dawn) are never charged with trafficking in clichés, because to do so would be anachronistic. Underlying the category of cliché is a modernist sense that words reflect something fundamental about individual 
authors' and speakers' selves. This understanding resonates with the modern Protestant project of defining subjects whose speech can reveal their 'sincere' character (Keane 2002).

Seen dispassionately, clichés are nimble creatures. They are the opposite of tired or dead matter, circulating widely and durably. Indeed, Joel Robbins observes that there are 'clichéd aspects of all cultural discourse' (2007: 12). But the tone of many critics of cliché is overwrought and elitist, from Eric Partridge's rant against 'half-education - that snare of the half-baked... an uncultured, little-reading person sees a stock phrase and thinks it apt and smart' (1978: 2) to Verlyn Klinkenborg's (2012: 45) description of it as brain-eating gangrene. The point of many critiques is that lazy people express themselves lazily and provoke lazy thoughts in a feedback loop of laziness.

Clichés are not limited to language. Various images, sounds, and artistic techniques have been characterised as clichés. Miles Davis, recalling his dissatisfaction with bebop jazz, said, “After a while, what was happening around New York became sickening, because everybody was playing the clichés that people had played five years before.... I really couldn't stand to hear most of those guys" (Szwed 2002: 74). ${ }^{1}$ Considering the category's wide scope, cliché is best understood simply as an accusation that meaning and effectiveness have been lost through excessive repetition. Clichés do not exist as clichés until they are called out as too successful: Their extensive circulation is pointed out and judged negatively. For something to be considered a cliché, first it has to be a notable success in terms of circulation, and second, it has to be articulated with an ideology that some repetition is excessive and points to some kind of deficiency in the author's or speaker's character. ${ }^{2}$

Applying the term 'cliché' to ritual might seem like a category error. The whole point of much ritual action is to repeat something - to replicate an established form in a new context. In some performance traditions, replicating ancestors' words verbatim is vital to ritual success, and in extreme cases fatal if done wrong (Lewis 2014). Moreover, in some 
contexts replication opens up new creative possibilities for participants (Bauman 2004: 128158). Niloofar Haeri (2013) describes Shi'ite women in Iran who pray privately. In reciting Quranic verses, 'what appears to take place over time is that while the forms of the versesthe words that make them up-remain unchanged (they are God's chosen words after all), their meanings proliferate' (2013: 20). Women focus on different possible interpretations over time and come to think of themselves as connecting with God in a deeply personal way as a result.

Yet ritual efficacy often depends on the overarching sense that this action is not being done for the first time, that there is a model for the pattern about to unfold, and that recreating it is desirable and ought to have particular results. The interlinked claims I am making might each be obvious, then, but they need explicit statement and articulation: (1) Not all ritual participants comment on replication; (2) When they do, it might be evaluated positively or negatively; (3) When it is evaluated negatively, the negative reaction might be (but is not necessarily) framed in terms of cliché, in which excessive repetition leads to loss of meaning.

So, when does ritual replication get treated as a kind of sanctified cliché? In a Blochian sense, ritual might be said to be 'clichéd' in the sense of being drained of creative meaning, although this extension of Bloch shifts the sense of cliché toward something ironically powerful, a distant cousin to George Orwell's sense of unoriginal English contributing to social decadence (and not only reflecting it). ${ }^{3}$ If ritual is like cliché from a Tambiahan perspective, it is when a rite becomes internally tedious, or is practiced too often in too many contexts, or becomes standardised to the point of inflexibility (Tambiah 1985: $161-162)$.

Comparing ritual and cliché in terms of their sign relationships can give analysts fresh insights. In simplified Peircean semiotics, significance depends on three kinds of relationship between signs and what they stand for, as apprehended by an interpreter: iconism (a 
relationship of resemblance, as a map resembles a territory), indexical (a relationship of connection, whether physical or logical, as dirty plates show a meal has been eaten), or symbolic (a conventional relationship, such as the definition of a word). No sign is exclusively icon, index, or symbol, but the relative force of one kind of relationship might be emphasized for any given sign by a particular interpreter in a given context.

Semiotic terminology can help clarify what is at stake in assessing the ways people evaluate repetition. If ritual form is supposed to be repeated in order to be effective, iconicity is something people pay attention to: did she speak the words correctly? Was he wearing the proper vestments? Did they move in the right direction? This is the classic force of tradition, the sense that a past form is inherently worthy and should be replicated mostly without deviation. The iconicity — the repetition — creatively indexes an effective performance. Conversely, if a ritual form is said to be repeated too often and thereby have lost meaning, the iconicity becomes a problem: too much sameness indexes the absence of purpose and vitality. This distinction is key to understanding different kinds of criticism indigenous Fijians make about kava drinking.

\section{'The Kava Has Been Pounded'}

Kava is a shrub grown widely in the South Pacific and the beverage made from pounding its dried roots and stems and infusing the powder into water. Drinking it usually 'evokes an atmosphere of relaxation and easy sociability' (Lebot, Merlin, and Lindstrom 1997: 1, 3). Many anthropologists would identify kava-drinking sessions as ritual events because, whether conducted for formal purposes or casual socialization, they are always regular collective acts contoured by replication, and are thought to have social and spiritual significance and efficacy beyond the instance of performance. 
To simplify for the sake of this article's argument, indigenous Fijian kava-drinking sessions can be classified into several kinds. When a major social event such as a wedding or funeral is held, kava is often drunk to mark the proceedings as significant. The installation of a chief with his or her title is an extremely formal version of such purposeful drinking, as I describe below. A second kind is the pre-Christian practice of drinking kava to summon spirits, whether to seek those spirits' advice or to ask them to do one's bidding. A third is casual, daily kava-drinking sessions which are held primarily for socialising — relaxing, chatting, making plans, and so forth. I will discuss each of these briefly before turning to the kinds of criticism one hears about kava drinking in the present day. ${ }^{4}$

Ratu Sir Kamisese Mara, who would become independent Fiji’s first prime minister, recalled the ceremonies in 1969 in which he was formally given the title of Tui Nayau, the paramount chieftainship of eastern Fiji’s Lau group (Mara 1997: 92-95). He had been traveling to Lau by boat, and was met by representatives (he does not say how many) who came on board to offer the "invitation to land," (cavu i kelekele). In doing so, the representatives presented a whale's tooth, the most valued Fijian ceremonial object. On landing, Ratu Mara walked along a strip of barkcloth lain down for him and went into a chiefly house for a welcome ceremony. The next day, when a traditional drum was beaten to signal the beginning of the installation, Ratu Mara was led up a hill toward the site, called Maumi, where he would be installed. He wrote:

By now in full Fijian dress, my wife and I were led up the hill, over yet more bark cloth carpets, by Vaka (the chief master of ceremonies).... On our arrival at Maumi, we were conducted to our appointed places under a palm-frond shelter, and Vaka placed on my head a turban of bark cloth.... Then the yaqona [kava] was mixed in an ancient bowl, and the attending minister said a prayer. 
With the eloquence that comes naturally to so many Fijians and rises to oratory on great occasions, Vaka spoke of the title of Tui Nayau, its history and its responsibilities, solemnly charged me with the care of the people, and promised undying fealty.

Then Vaka tied a strip of fine white bark cloth on my right arm and offered me a bowl of yaqona. Uniquely in Fijian ceremony, the cup was passed to me backwards over Vaka's head as he sat with his back to me. Neither the origin nor the meaning of this custom is known. But the next, when the bowl of yaqona is followed by a bowl of water, may simply be the Fijian equivalent of the "chaser." After I had drunk, all those present performed the cobo [ceremonially significant clapping], and [I] had become Tui Nayau. Next to drink was Vaka, then Adi Lala [Ratu Mara's wife]—now Radi ni Nayau - and she was followed by Matakicicia. The other chiefs then drank in the order ordained by Vaka. (Mara 1997: 93)

Although Ratu Mara says the meaning of the unusual cup presentation-being passed backwards to him, over the head of the man leading the ceremony-is not known, Marshall Sahlins (1985: chapter 3) has offered an influential interpretation of the ceremony based on the Frazerian warrant that kings need to be killed in order to rule legitimately. That first cup of kava, Sahlins notes, symbolically poisons the chief. This is why only the chief drinks a cup of fresh water afterward, because he is the person who has been killed, and now needs to be restored to life. In doing so, he truly becomes Tui Nayau. ${ }^{5}$

It might be objected that chiefly installation ceremonies are not kava-drinking ceremonies per se, because kava is just one of a host of symbolic elements brought together: barkcloth, whalesteeth, drumbeats, feast foods. From this perspective, calling a chiefly installation ceremony a kava session would be like comparing Holy Communion to a wine 
tasting. Such an objection would miss the point that this kind of formal ceremony is an ideal—a model of how things are done with utmost respect for tradition; an especially effective instance; crucially, how things were done in the old days. And indeed, many chiefly installation rituals do not take place nowadays due to local disagreements (see Nayacakalou 1975: 62-63; Toren 1994; Eräsaari 2013 75-76, 111, 222-223). When purposeful and highly formalised kava-drinking sessions are held today, they are often for events like marriages, funerals, and welcomes, marking the events' importance.

Kava drinking has long been associated with non-Christian spirits, and this connection underlies the second kind of usage. Many examples in the historical and ethnographic literature describe various uses: for instance, tossing kava into rough seas to calm the god stirring them up, or tying kava to a wharf so that a sea god will bless a nighttime fishing expedition; pouring kava onto a grave for sorcery in which the dead will curse a living descendant, or, conversely, drinking kava in public to cure sickness caused by evil magic (see, respectively, Williams 1982 [1858]: 89; St. Johnston 1918: 123-124; Lambert 1938; Toren 1988: 704; see also Tomlinson 2009: chapter 4). ${ }^{6}$ Curing could rely on kava-mediated visions (Spencer 1941: 55; compare Katz 1993: 284), and traditional priests could see past, present, and future events in the liquid's surface (Kaplan 1995: 209). ${ }^{7}$

The ability to see the future with the help of kava was useful in warfare. Consider the events of Wednesday, March 22, 1854: Embroiled in their long war against the chiefdom of Rewa, the chiefs of Bau met with their priests. The chiefs asked the god Cagawalu for success in a campaign they planned against the people of Kaba, who formerly served Bau but had defected to Rewa. The god, speaking through his priest, announced that Bau would indeed be successful, adding: 'Go, hasten to destroy them. Do I not give them up to your pleasure?' The god indicated that he was about to leave, so six younger chiefs brought him kava served in banana leaves, giving one to the priest to drink and pouring out the others as 
offerings, after which 'the deity exclaimed, "Goodbye! I am going"; and the wretched performance was at an end' (Waterhouse 1997 [1866]: 163-164). Note, whereas Waterhouse describes kava being drunk to close the interaction, Hocart (1952: 12) describes it as precipitating the event: "when the shaman [sic] drinks the offered kava the spirit comes down the curtain of the temple and "jumps" or "embarks" on him, so that he goes into a fit and prophesies. ${ }^{9}$

Underpinning kava's link with the spirit world is its symbolism as wai ni vanua, 'water of the vапиа'. Vапиа is an emotionally weighty and socially encompassing category of land and people within a chiefdom. Turned into an adjective (vakavanua), it connotes the 'traditional' order. The vanua as land-and-people is what 'kills' a chief who drinks the ceremonial cup of installation, who is thereafter able to lead and represent the vanua. Drinking kava reflects respect for tradition, which is one reason evangelical Christians who want to make a decisive break with tradition forbid its consumption, a point I return to below.

Most kava sessions are neither highly formal events nor intentional engagements with old spirits. They are relaxed, casual, everyday affairs, pleasant drinking sessions of several hours each evening. In casual kava-drinking sessions, no one treads on barkcloth carpets or presents whales' teeth. People converse, tell stories, joke, and smoke cigarettes, and there is no larger purpose beyond socialising. The mood is relaxed. Being a member of a mainstream church in Fiji means you will likely drink a lot of kava regularly. Where I conducted research in rural Kadavu Island, many men drank for several hours every day. Women also drank, although less often than men. Drinking sometimes took place within the Methodist church compound but never inside the church itself. Because of its social centrality, drinking kava in Fiji is 'virtually obligatory,' as Christina Toren put it based on her work in Gau Island; it is 'an act that both expresses and in part constitutes a particular and ritually defined social 
order' (Toren 1988: 704, 1999: 33; see also Eräsaari 2013: 46-51; Toren 1990, Tomlinson 2014: chapter 3).

Although kava-drinking sessions have undergone significant historical changes in purpose, symbolism, and participant structure (Abramson 2005), they are inherently conservative rituals in the sense that even the most relaxed sessions follow a standard structure and rules. At the start of every session, formulaic announcements are made in rhythmically modulated speech to mark the beginning of preparation and the beginning of service; at the end, a similar kind of announcement closes the event. In my experiences of drinking kava in Fiji at hundreds of sessions, I have never heard these announcements omitted. Drinkers are served in a consistent order, roughly from the highest ranked person in the room to the lowest, with possible minor variations and some room for negotiating the precise order. There are standards of clapping and verbal response when one drinks and when others drink (see Tomlinson 2009: 112-114). When experienced day-by-day, kava sessions have a comforting sameness. First come the announcements; then come many rounds in which each person drinks his or her individual cup in order, service getting slower over the hours as people become 'drunk;' then comes formulaic closure. And then, sometimes, people drink more after the closure, either more kava or a 'washdown' of alcohol (the English term is used).

Kava sessions are hierarchical in their order and method of service. They are also democratic in having each drinker consume one cup per round, with many non-chiefly drinkers sharing the same coconut-shell cup. ${ }^{9}$ In bringing together chiefs and people, these sessions both create and reflect the category of the vanua, or indigenous Fijian polity-andterritory. But the vanua is changing. As Christina Toren has pointed out, kava-drinking is thought to stand for a true Fijian way of life even as people recognise that kava is drunk differently than it was in the old days, and the chiefly authority to which kava sessions call 
attention is socially waning (1988: 704-706; see also Abramson 2005, Tomlinson 2007). As central sites of socialisation, kava-drinking sessions are richly dialogic contexts in which members of a rapidly changing society reflect on social changes, including perceived changes in kava-drinking norms.

In both constituting and expressing the social order, as Toren puts it, kava opens up spaces of ambiguity. It indexes many possible meanings, some of them notably opposed. Kava is a drink enjoyed by many devout Christians but associated with non-Christian spirits. It can be used to harm, and it can be used to heal. It is a drink tied to respect for chiefly traditions, and also a way of hanging out casually every evening. A man who drinks it in great quantities both proves that he is the ideal Fijian man and prevents himself from being the ideal Fijian man. ${ }^{10}$ In pulling opposed meanings together like this, kava-drinking sessions display the 'exceptionally dense representation of spatiotemporally wider categories and principles in an interactional here-now' which Stasch identifies as the hallmark of ritual (2011: 160).

The key ambiguity seen in kava's proliferation of meanings is its status as a cherished traditional beverage drunk enthusiastically by devout Christians who, according to the evangelical line of criticism I will soon discuss, are thereby subverting Christianity. The modern indigenous Fijian vanua is a markedly Christian space. God is said to have given indigenous Fijians the land as a divine inheritance. Drinking kava should thus logically be an act of worshiping God, but its link with pre-Christian ancestors means kava is a Christian symbol only in an oblique and contested way (Tomlinson 2014: chapter 3). In drinking kava faithfully day by day, indigenous Fijians collectively make the vanua a vibrant, identifiable body in the same way Sahlins argues was once the responsibility of paramount chiefs- to 'ritually recreate...the social world every day' by drinking kava (1991: 66). But the ritually constituted body, still constituted in terms of chiefdoms but now thoroughly Christian and 
more democratic, always retains a link to non-Christian figures because kava is a conduit to them.

\section{Public Criticism: 'It's Not Meaningful'}

There are two main kinds of public criticism of kava drinking in indigenous Fiji. Each focuses on a different sign relationship. The first kind of criticism, which I will call 'evangelical', has two parts to it. First, it makes you drunk. Or rather, it relaxes your muscles and induces a pleasant, sociable feeling. This is called being drunk (mateni) on kava, although kava is not alcoholic and both the drunkenness and the hangover from kava are entirely different from those of alcohol (Aporosa and Tomlinson 2014). Second, it connects you with non-Christian spirits, including ancestral ones. One man in Kadavu described the connection between a person and a spirit he or she serves as being 'covenanted' (viyalayalaji), a relationship in which the person's drinking of kava means the spirit also 'drinks' it; and a Methodist minister participating in the conversation said he often spoke a prayer at kava sessions because people may have been serving spirits silently there (see Tomlinson 2009: 128). In short, kava 'enhances communication' with potentially dangerous spirits (Turner 1986: 209; see also Ravuvu 1987: 25; Spencer 1941: 12). As a result, evangelicals forbid its consumption, and even enthusiastic drinkers in the Methodist Church have a degree of awareness and caution about the spiritual aspects of drinking kava with bad intentions. In the evangelical line, then, the weight of criticism is on kava drinking's indexicality, what it 'points to': either indulgence or, more worryingly, the dangerous spirits who are summoned.

In 2006, I interviewed a paramount chief in Kadavu who was an evangelical Christian. He shared his view of the relationship between kava and communication with spirits. He observed that before kava is mixed, someone makes the formulaic announcement 
'The kava has been pounded' (Sa vutu kora tu na yaqona); the response 'Mix' (Bali) is then given by the matanivanua (vanua's representative, who mediates between chiefs and people; see Tomlinson 2009: 112). But, the chief asked me, who are you (really) calling to with this announcement? I thought I knew where he was heading but wanted to draw him out, so I suggested that it was the chiefs who were being addressed. But why say it aloud? he persisted. I asked him to explain. So he said that when a person made this kind of announcement, there was actually 'something else you want to announce' ( $e$ dua tani tale na ka o iko via kaciva). Pre-Christian spirits were traditionally summoned by priests with kava, he said, and his implication was that people making the formulaic announcements today were doing the same thing. That is, they were calling forth evil spirits. To take his argument seriously means that before the first drop is consumed, the replication of formulaic announcements ensures that one has already caused a problem by inviting dangerous spirits to show up. ${ }^{11}$ This view is not shared by Fijian Methodists who believe that one can drink kava and be a good Christian, too.

I will call the second kind of criticism 'chiefly,' although it is not only expressed by chiefs and, as the last example shows, some chiefs are themselves evangelical Christians. Chiefly criticism identifies iconic repetition as the main problem, a wearing-out of original meanings and purposes. In the present day, I often heard, too many people drink kavapeople who supposedly could not drink in the old days, with women held up as the main example. Kava was also said to be drunk too often: each day now, not only on special occasions. Finally, it was said to be drunk in too much quantity, and here the chiefly criticism starts to merge with the evangelical criticism of drunkenness. As with cliché, the underlying theme is laziness: Men who drink too much kava are said to be lazy, failing to work hard or satisfy their wives and neglecting their children, for example. ${ }^{12}$ 
Media reports invoke the stereotypical colonial-capitalist figure of the 'lazy native' (Alatas 1977) in accusations about excessive kava drinking. One newspaper reported Ratu Mara saying in 1999 that people who drank too much kava were 'weak the next morning and they cannot attend to what they should be doing' (Fiji's Daily Post 1999). In 2005, the chief executive officer of the Public Service Commission announced that civil servants should not drink kava at work, and the police commissioner implemented a 'zero tolerance' policy for officers on duty (Fiji Times 2005a). An editorial in the leading daily newspaper expressed the chiefly line of criticism strongly, with its balance of overt respect for tradition and denunciation of 'abuse':

Yaqona [kava] has its special place in Fijian culture. No one doubts that. Nothing can diminish or take away its traditional significance during Fijian ceremonies.

But because the local beverage has been extensively abused to the point that it is the cause of social and economic problems for some families and individuals, many people are now more wary of its ill-effects.

A heavy session of yaqona the previous night forces workers to be late for or miss work....

Not only Fijian families but increasingly also some Indians ${ }^{13}$ are into [this] serious yaqona drinking in the evenings. Some drink yaqona while working during the day and continue when they reach home.

We all know that if consumed excessively, yaqona not only affects one's health but also one's productivity. It makes one lazy and slow. (Fiji Times 2005b).

That same year, the National Substance Abuse Council reported that kava was the drug most often tried by secondary school students, with 69 percent having done so (Singh 2005; 
alcohol followed at 51 percent, tobacco at 43 percent, and marijuana at 13 percent). The headline of the article announcing these figures sounded the alarm: 'Substance abuse rife among pupils.'

I call this kind of criticism 'chiefly' because it laments the democratization of kavadrinking: the fact that anyone can drink it today, not just chiefs; and that although it is always served at major events, it is drunk far more often on relatively unimportant occasions. One man in Kadavu expressed the point succinctly when he told me that these days, kava was drunk when 'it's not meaningful' (mino ni vaibalebale); another man, on another occasion, made the same claim in a positive vein, explaining that kava should be drunk 'so it has a meaning [i.e., a purpose]' (me jiko i dua na kena ibalebale; see Tomlinson 2009: 122). This is the underlying sense of cliché in which ritual becomes a target of reformers. Only evangelicals ban kava. Chiefly critics want it consumed, but only on proper occasions and by the right people, not promiscuously. Kava's chiefly critics do not object to kava drinking in itself, nor to ritual in general, but to what the ritual has become. This double sensibility was expressed clearly by the president of Fiji's Methodist Church, who explained in the late 1990s that 'the use of yaqona [kava] is too much...it should be taken in moderation,' and also that it was 'a gift from God and people were morally obliged to consume it' (Tomlinson 2009: 126, 128).

In the chiefly line of criticism, then, iconicity is the main problem-there is too much repetition, too much sameness - but this iconicity has an indexical aspect, namely, it points to socialising rather than to chiefly ceremony. Indexically, kava-drinking is supposed to mark particular occasions as purposeful and significant ones. Or, to phrase this claim negatively: You can't install a chief without serving that sacred cup, and if a Methodist funeral did not have kava drinking as part of the proceedings, it would send a disturbing message about the event's unimportance. In routine, daily drinking, however, there is no event for the session to 
point to other than itself. The rules of service are always followed, but at casual sessions, the purpose of the gathering is to relax and talk.

In public criticism of kava drinking, ambiguity can arise from the fact that different kinds of criticism seem, on the surface, to be the same thing. At least, this was my initial difficulty in sorting out the various things I was hearing. When critics say kava makes you 'drunk', they might be grounding this claim in the evangelical sense that kava-drinking sessions are ungodly, even down to the words spoken to begin them. Or, they might be grounding this claim in chiefly criticism of excess: It's too much. But these criticisms have different logics. The evangelical criticism holds kava's indexical-iconic force to be essentially non-Christian, tied to a spiritual world that should be rejected. The chiefly criticism is that kava's indexical-iconic force should not be diluted through repetition.

\section{Conclusion}

Because replication is a common feature of ritual within and across performances, analysts of ritual ought to pay attention to people's expectations of what counts as replication and why it matters. This is perhaps obvious - an anthropological truism. But the question of when and how people criticise ritual for its consistent replication demands attention to the sign relationships in which iconic resemblance and indexical connection are aligned in ways people find problematic.

Kava drinking fosters sociality. It brings people together every day. In doing so, it both reflects and reinforces its symbolic role as the wai ni vanua, 'water of the vanua'- $\mathbf{a}$ fluid that unites land, people, and their chiefs. The ritual formality of kava-drinking sessions, and the fact that they are replicated every day in places like Kadavu, demonstrates their significance for indigenous Fijian sociality as an emblem of immense and enduring value. Yet by bringing people together in perceived excess, kava-drinking sessions are open to the 
criticism that they threaten social bonds - weakening men's willingness to work the next morning, causing them to neglect their responsibilities toward wives and children-as well as, for some critics, people's devotion to God.

One kind of criticism, which I have called evangelical, does not focus on replication as the problem, but on drunkenness and the performative force of summoning non-Christian spirits. Another kind of criticism, which I have called chiefly, does focus on replication, claiming that today too many people drink too much, too often. Although everyone follows ritual formalities at even the most casual session, there is a key difference between a formal one (in which, say, a chief is installed, a guest is welcomed, or a couple's marriage is celebrated) and an informal one which is just pleasant socialisation. The arrow of indexicality, in the latter case, points back at the session itself.

A ritual performance cannot be considered a cliché if replication is thought to be integral to the performance's success, and therefore actively sought and positively evaluated. A cliché depends on a negative evaluation of replication based on the sense that it is happening too much, wearing down meaning. So, is there a relationship between ritual and cliché? Yes, I have argued, when repetition is framed as a problem of both iconicityexcessive repetition - and also the indexical force of that iconicity, which points to loss rather than endurance of meaning. In the case of casual kava-drinking sessions, the iconic repetition of form is taken by critics to show that the indexical link to chiefliness has been lost even as old patterns of service are followed correctly. This kind of criticism of ritual practice treats it as a cliché. The analysis offered in this article will hopefully be of use to other scholars investigating contexts in which replication, a hallmark of ritual, is identified by critics as a problem in itself and a symptom of a deeper problem. 


\section{Sources}

Abramson, Allen. 2005. Drinking to Mana and Ethnicity: Trajectories of Yaqona Practice and Symbolism in Eastern Fiji. Oceania 75(4): 325-341.

Alatas, Syed Hussein. 1977. The Myth of the Lazy Native: A Study of the Image of the Malays, Filipinos and Javanese from the 16th to the 20th Century and Its Function in the Ideology of Colonial Capitalism. London: Frank Cass.

Amossy, Ruth. 1982. The Cliché in the Reading Process, trans. Terese Lyons. SubStance 11(2): 34-45.

Aporosa, S. 2014. Yaqona (Kava) and Education in Fiji: Investigating 'Cultural Complexities' from a Post-Development Perspective. Albany, New Zealand: Massey University, Directorate Pasifika@ Massey.

Aporosa, S. 2015. The New Kava User: Diasporic Identity Formation in Reverse. New Zealand Sociology 30(4): 58-77.

Aporosa, S., and Matt Tomlinson. 2014. Kava Hangover and Gold-Standard Science. Anthropologica 56: 163-175.

Bauman, Richard. 2004. A World of Others' Words: Cross-Cultural Perspectives on Intertextuality. Malden, MA: Blackwell. 
Coulter, John Wesley. 1942. Fiji: Little India of the Pacific. Chicago: University of Chicago Press.

Deane, W. 1921. Fijian Society: Or the Sociology and Psychology of the Fijians. London: Macmillan.

Eisenlohr, Patrick. 2010. Materialities of Entextualization: The Domestication of Sound Reproduction in Mauritian Muslim Devotional Practices. Journal of Linguistic Anthropology 20(2): 314-333.

Eräsaari, Matti. 2013. "We Are the Originals": A Study of Value in Fiji. Ph.D. dissertation, University of Helsinki.

Fiji's Daily Post. 1999. Ratu Mara Warns over Kava Abuse. August 13, page 5.

Fiji Times. 2005a. Civil Servants Told Not to Drink Yaqona at Work. December 21, pp. 1-2.

Fiji Times. 2005b. Yaqona at Work. December 21, p. 6.

Haeri, Niloofar. 2013. The Private Performance of Salat Prayers: Repetition, Time, and Meaning. Anthropological Quarterly 86(1): 5-34.

Hargraves, Orin. 2014. It's Been Said Before: A Guide to the Use and Abuse of Clichés. Oxford: Oxford University Press. 
Hocart, A.M. 1929. Lau Islands, Fiji. Honolulu: Bernice P. Bishop Museum.

Hocart, A.M. 1952. The Northern States of Fiji. London: Royal Anthropological Institute of Great Britain and Ireland.

Ilie, Cornelia. 2000. Cliché-Based Metadiscursive Argumentation in the Houses of Parliament. International Journal of Applied Linguistics 10(1): 65-84.

Jayawardena, Chandra. 1971. The Disintegration of Caste in Fiji Indian Rural Society. In Anthropology in Oceania: Essays Presented to Ian Hogbin, eds. L.R. Hiatt and C. Jayawardena, pp. 89-119. Sydney: Angus and Robertson.

Kaplan, Martha. 1995. Neither Cargo Nor Cult: Ritual Politics and the Colonial Imagination in Fiji. Durham, NC: Duke University Press.

Kasuga, Naoki. n.d. A Pacific Island Rasputin: The Viti Kabani Movement in Fiji. Unpublished manuscript.

Katz, Richard. 1993. The Straight Path: A Story of Healing and Transformation in Fiji. Reading, Massachusetts: Addison-Wesley.

Keane, Webb. 1995. The Spoken House: Text, Act, and Object in Eastern Indonesia. American Ethnologist 22(1): 102-124.

Keane, Webb. 1997a. Religious Language. Annual Review of Anthropology 26:47-71. 
Keane, Webb. 1997b. Signs of Recognition: Powers and Hazards of Representation in an Indonesian Society. Berkeley: University of California Press.

Keane, Webb. 2002. Sincerity, "Modernity," and the Protestants. Cultural Anthropology 17(1): 65-92.

Keane, Webb. 2007. Christian Moderns: Freedom and Fetish in the Mission Encounter. Berkeley: University of California Press.

Kertzer, David. 1988. Ritual, Politics, and Power. New Haven: Yale University Press.

Klinkenborg, Verlyn. 2012. Several Short Sentences about Writing. New York: Alfred A. Knopf.

Kuhn, Thomas S. 1970. The Structure of Scientific Revolutions, 2nd ed. Chicago: University of Chicago Press.

Lambert, Sylvester M. 1938. Draunikau and Magic Notes: Article XI, October 11. MSS 0682, Box 2, Mandeville Special Collections Library, University of California at San Diego.

Lebot, Vincent, Mark Merlin, and Lamont Lindstrom. 1997 [1992]. Kava: The Pacific Elixir. Rochester, VT: Healing Arts Press.

Lerner, Laurence D. 1956. Cliché and Commonplace. Essays in Criticism 6(3): 249-265. 
Lewin, Louis. 1931 [1924]. Phantastica, Narcotic and Stimulating Drugs: Their Use and Abuse, trans. P.H.A. Wirth. London: Kegan Paul, Trench, Trubner \& Co.

Lewis, E. Douglas. 2014. Parallelism and Chiasmus in Ritual Oration and Ostension in Tana Wai Brama, Eastern Indonesia. In Chiasmus and Culture, eds. Boris Wiseman and A. Paul, pp. 187-218. New York: Berghahn.

Mara, Ratu Sir Kamisese. 1997. The Pacific Way: A Memoir. Honolulu: University of Hawai'i Press.

Mayer, Adrian C. 1973. Peasants in the Pacific: A Study of Fiji Indian Rural Society, 2nd ed. London: Routledge \& Kegan Paul.

Myerhoff, Barbara G. 1984. A Death in Due Time: Construction of Self and Culture in Ritual Drama. In Rite, Drama, Festival, Spectacle: Rehearsals Toward a Theory of Cultural Performance, ed. J.J. MacAloon, pp. 149-178. Philadelphia: Institute for the Study of Human Issues.

Nayacakalou, R.R. 1975. Leadership in Fiji. Melbourne: Oxford University Press.

Newland, Lynda. 2004. Turning the Spirits into Witchcraft: Pentecostalism in Fijian Villages. Oceania 75(1): 1-18. 
Orwell, George. 1968. Politics and the English Language. In The Collected Essays, Journalism and Letters of George Orwell, ed. Sonia Orwell and Ian Angos, vol. 4, pp. 127140.

Partridge, Eric. 1978. A Dictionary of Clichés, 5th edition. Abingdon, Oxon: Routledge.

Rappaport, Roy A. 1999. Ritual and Religion in the Making of Humanity. Cambridge: Cambridge University Press.

Ravuvu, Asesela D. 1987. The Fijian Ethos. Suva: Institute of Pacific Studies, University of the South Pacific.

Robbins, Joel. 2007. Continuity Thinking and the Problem of Christian Culture: Belief, Time, and the Anthropology of Christianity. Current Anthropology 48(1): 5-17.

Sahlins, Marshall. 1985. Islands of History. Chicago: University of Chicago Press.

Sahlins, Marshall. 1991. The Return of the Event, Again: With Reflections on the Beginnings of the Great Fijian War of 1843 to 1855 between the Kingdoms of Bau and Rewa. In Clio in Oceania: Toward a Historical Anthropology, ed. A. Biersack, pp. 37-99. Washington, DC: Smithsonian Institution Press.

Shoaps, Robin. 1999. The Many Voices of Rush Limbaugh: The Use of Transposition in Constructing a Rhetoric of Common Sense. Text 19(3): 399-437. 
Shoaps, Robin. 2002. "Pray Earnestly": The Textual Construction of Personal Involvement in Pentecostal Prayer and Song. Journal of Linguistic Anthropology 12(1): 34-71.

Singh, Monika. 2005. Substance Abuse Rife among Pupils. Fiji Times, December 13, page 1.

Spencer, Dorothy M. 1941. Disease, Religion and Society in the Fiji Islands. Seattle: University of Washington Press.

Stasch, Rupert. 2011. Ritual and Oratory Revisited: The Semiotics of Effective Action. Annual Review of Anthropology 40: 159-174.

St. Johnston, T.R. 1918. The Lau Islands (Fiji): And Their Fairy Tales and Folk-lore. London: Times Book Co.

Szwed, John. 2002. So What: The Life of Miles Davis. London: Arrow Books.

Tambiah, Stanley Jeyaraja. 1985 [1979]. A Performative Approach to Ritual. In S.J.

Tambiah, Culture, Thought, and Social Action: An Anthropological Perspective. Cambridge, MA: Harvard University Press.

Tomlinson, Matt. 2007. Everything and Its Opposite: Kava Drinking in Fiji. Anthropological Quarterly 80(4): 1065-1081.

Tomlinson, Matt. 2009. In God's Image: The Metaculture of Fijian Christianity. Berkeley: University of California Press. 
Tomlinson, Matt. 2014. Ritual Textuality: Pattern and Motion in Performance. New York: Oxford University Press.

Toren, Christina. 1988. Making the Present, Revealing the Past: The Mutability and Continuity of Tradition as Process. Man (n.s.) 23(4): 696-717.

Toren, Christina. 1990. Making Sense of Hierarchy: Cognition as Social Process in Fiji. London: Athlone Press.

Toren, Christina. 1994. All Things Go in Pairs, or the Sharks Will Bite: The Antithetical Nature of Fijian Chiefship. Oceania 64(3): 197-216.

Toren, Christina. 1999 [1989]. Drinking Cash: The Purification of Money through Ceremonial Exchange in Fiji. In C. Toren, Mind, Materiality and History: Explorations in Fijian Ethnography. London: Routledge.

Turner, James W. 1986. 'The Water of Life': Kava Ritual and the Logic of Sacrifice. Ethnology 25(3): 203-214.

Urban, Greg. 2001. Metaculture: How Culture Moves through the World. Minneapolis: University of Minnesota Press. 
Veramu, Joseph C. 1992. Let's Do It Our Way: A Case Study of Participatory Education in a Rural Fijian School and Community. Suva: Institute of Pacific Studies, University of the South Pacific.

Vuetanavanua, Savenaca. 2009. Veibuli (Chiefly Installation): A Theological Exploration. Master of Theology thesis, University of Auckland.

Waterhouse, Joseph. 1997 [1866]. The King and People of Fiji. Auckland: Pasifika Press.

Williams, Thomas. 1982 [1858]. Fiji and the Fijians, vol. 1. Suva: Fiji Museum.

\footnotetext{
${ }^{1}$ One could go further and consider lives and scholarship as kinds of clichés, per Naipaul's arch invocation of postcolonial 'mimic men' who 'pretended to be real' (1969: 146), Geertz's critique of the anthropologists of religion 'parading habitual skills' (1973: 88), and Kuhn's (1970) analysis of the blinkered methods of 'normal science'. These denigrations of repetition follow the cliché model, identifying repetition as inherently bad because it is not new, and newness as a key aspect—even essence — of intellectual and aesthetic value (Urban 2001).
}

${ }^{2}$ Lerner (1956) adds the questionable criterion that a cliché is meant to be 'sensational,' and even proposes that one might invent a new cliché (the one he comes up with is 'talking with the brakes off'). Although I disagree with his narrow if novel understanding, Lerner's characterization of cliché as 'the bad side of originality' (265) is useful for the way it condenses the expectation of originality with its perceived failure. 
${ }^{3}$ In 'Politics and the English Language,' George Orwell does not use the term 'cliché,' but nonetheless reveals a language ideology grounded in critical abhorrence of it: Modern English writing is 'phrases tacked together like the sections of a pre-fabricated hen-house,' demonstrating a decline in which 'the slovenliness of our language makes it easier for us to have foolish thoughts' $(1968: 128,130)$. The modernist certainty that novelty is the key marker of value is itself a cliché about clichés. As Ilie (2000: 67) observes, 'the definitions of clichés have a tendency to turn into clichés themselves' (see also Lerner 1956).

${ }^{4}$ My point is not to offer a strict classification, but to ground the discussion of criticism to follow. A single continuous kava-drinking session can change in character as the hours unfold, and a session can combine a purpose with casualness, as when people gather to listen to a rugby game on the radio. In addition, as Allen Abramson points out, kava has become a commercial emblem of Fijian indigeneity, offered at hotels to tourists looking for liquid authenticity: 'Paradoxically,' he observes, this kind of kava session 'must become less Fijian for Fijians in order to become more Fijian for tourists' (2005: 329). In this article, I do not examine kava-drinking for touristic purposes, but it might well be considered another variety, in addition to overseas adaptations by drinkers of non-Oceanic heritage (Aporosa 2015).

${ }^{5}$ Naoki Kasuga (n.d.) describes a radical innovation on this form made by the prophetic economic reformer Apolosi Nawai in the early decades of the twentieth century. Nawai founded the Viti Kabani or 'Fiji Company' which functioned as 'an alternative government' said to be sanctioned by Jehovah and pre-Christian Fijian deities (Kaplan 1995: 133). Kasuga quotes a colonial official who reported in 1929 that Nawai was letting people know a plague would come the following year. To protect themselves, they had to purify themselves by mixing a bowl of kava that was apparently held over Nawai's head 'whilst he utters the 
necessary words - the person concerned then empties the [kava bowl] outside' (Kasuga n.d.: 135). Holding a bowl over someone's head while mixing is an inversion of the spatial norm in which people are seated around the bowl on the floor. Presumably, Nawai meant to symbolise both his submission to and his connection with the spiritual power inherent in the kava. Even more radically, he once entered a church building in the Yasawa Islands and reportedly 'poured kava over his head and prayed to "God"... with his eyes opened' and finished his prayer, apparently on this and other occasions, by saying 'Lord, the rest is for you to decide' (Turaga, kena vo mo ni qai lewa; Kasuga n.d.: 137). This innovation on baptism would likely strike some modern-day Fijians as demonic (see Newland 2004; Tomlinson 2009: 127). Nawai apparently meant it, however, as a demonstration of his connection with spiritual power which was grounded at least partly in Christianity.

${ }^{6}$ In the second example, the god is explicitly identified as Dakuwaqa, who takes the form of a shark; in the first one it could also be Dakuwaqa who is being propitiated. See also Deane (1921: 30).

${ }^{7}$ A bowlful of kava 'resembles an infusion of coffee with milk' (Lewin 1931: 222) and there 'appears to be a very thin oily film on the surface of mixed kava that moves and changes as it reflects the light... [which] gives the kava the appearance of being "visually alive"" (Aporosa, personal communication, January 12, 2016).

${ }^{8}$ See also Waterhouse 1997 [1866]: 256-257 on similar service to the seafaring god Daucina, and ibid.: 258 for the observation that the agricultural god Ratumaibulu does not drink kava, but that his priest, after Ratumaibulu departs, 'partakes very gratefully of a copious draught of the kava' (see also Williams 1982 [1858]: 224-225). Waterhouse also mentions priests 
who, rather than ingest kava on behalf of their gods, consume (either in pretend or in part) stones or flaming coals (1997 [1866]: 289-290).

${ }^{9}$ In my experience in Kadavu, all men at kava-drinking sessions who were not evangelical Christians were expected to drink one cup per round. An evangelical Christian might attend a session to socialize, but not drink. Women were allowed to drink or abstain each round as they chose. See Toren's work for analysis of how kava-session service 'contains' balanced reciprocity (sides 'facing each other') and transforms it into relationships in which chiefs are paid tribute (Toren 1988, 1990: chapter 5, 1994, 1999).

${ }^{10}$ Because of kava's many opposed meanings, the ethnographic literature contains amusingly contrary observations. Richard Katz, studying healing, reported: 'When I talk with Ratu Noa, we certainly drink a lot of [kava]... But though we drink a lot, we don't drink to get drunk. No matter how many [bowls] we mix, we seem to talk about important things.... As we spend time together, hour after hour, we enter a special space. Truth lives there' (Katz 1993: 190-191, 281). Conversely, Joseph Veramu has observed: 'The topics of discussion in many [kava] drinking sessions where youths predominate is often of sexual affairs and the girls who are willing to have coitus in the cassava patch, by the beach, the community or youth hall (when it is empty), and other convenient areas' (Veramu 1992: 86).' Both are true, but reconciling them too neatly can only lead in the direction of nightclub humour.

${ }^{11}$ For the interview transcript and a discussion, see Tomlinson (2014: 64-66; see also Aporosa 2014: 117n57). The chief's claim highlights one ambiguity of kava-drinking sessions as ritual events. In contrast to many forms of indigenous Fijian ritual speech, the addressees for the kava announcements are not named. One could (as I tried) interpret it as an 
announcement made to the living chiefs who would be drinking, but the chief thought otherwise. When he uttered the words of announcement to me in order to criticise them as an invocation of demons, he did not, presumably, think that he was summoning evil spirits himself. He was just explaining something to an ignorant anthropologist, using the words in order to identify the problem as he saw it, and the problem had nothing to do with repetition. Rather, it was the performative force of the announcement: the way it summoned spirits who should be unwelcome. Yet the announcement is ambiguous in terms of its audience.

What Webb Keane has written about ritual speech in Sumba, Indonesia, is apt for indigenous Fijian kava-session announcements: 'ritual speech addresses an other, human or spirit, across some sort of social or ontological difference... The gap between interlocutors poses difficulties that require... special communicative efforts to overcome them' (Keane 1995: 106; see also Keane 1997a, 1997b, 2007). One strategy is to speak reflexively, naming and calling attention to 'the things, agents, and types of action involved in the actual event' where the words are spoken (Keane 1995: 106-107). Another is to speak formally and formulaically, using poetic 'canonical language' to give the words 'aesthetic power, textlike qualities, and ancestral character' (107). Kava-session announcements are this kind of reflexive formal speech, suggesting that a double gap is crossed in their utterance: those preparing the kava (the servers) are speaking to the chiefs (the served), but they might also be speaking to those who are present but invisible. Again, I expect many Methodists would reject this; but recall the Methodist minister's statement that he prayed at kava sessions in case people were serving non-Christian spirits there in silence.

${ }^{12}$ People who drink a lot of kava for a long time also develop a dry-skin condition, its own indexical icon of sorts. While this scaly skin can be covered up as a sign of shame, it can also 
be displayed proudly by kava advocates as a tattoo of masculine strength, a 'badge of honour' showing that one is a true indigenous Fijian man; see Aporosa (2014: 142n73).

13 'Indians' or Indo-Fijians are citizens of South Asian heritage, many of whose ancestors immigrated as indentured laborers in the early colonial period. Jayawardena (1971: 105) makes it clear that casual kava drinking was popular among Indo-Fijians at the time of his research in the 1960s; see also Coulter (1942: 92) and Mayer (1973: 47n1). 